Article

\title{
Gerald in the middle: Hybridity and historical narratives in History and Topography of Ireland and The Conquest of Ireland
}

\author{
Matthew Xavier Vernon \\ University of California, Davis, CA, USA.
}

\begin{abstract}
This article is interested in Gerald's mediating stance as he negotiates the complex relationship between genre and genealogy, between, that is, the precedent of history writing in England and his personal interventions within that history as inflected by his identification as descendant of the Britons. Gerald formulates his role as a historian in a way that resists the resolution usually sought by arguments about him. I propose a reading of Gerald as a "colonized intellectual," a term I borrow from Black Studies and postcolonial theory. Although the term emerges from a vastly different historical and political situation than Gerald's, the idea of the "colonized intellectual" encapsulates the paradox of Gerald's intellectual production and his political position within twelfth-century British society.
\end{abstract}

postmedieval: a journal of medieval cultural studies (2017). 8, 404-424. https://doi.org/10.1057/s41280-016-0013-3

There is a trend in the scholarship on Gerald of Wales to try to render what is crooked straight. The contradictions between what is known about Gerald's genealogy, his performance of his Norman and Welsh identity, and his sometimes imperialist, sometimes postcolonial writings all seem to demand reconciliation under a rubric that can account for and draw together the several 
sides of Gerald, much as he himself does with the hybrid creatures he profiles in his History and Topography of Ireland. Consider, for example, the recent provocative analysis of Gerald's History of Topography of Wales, in Michael A. Faletra's Wales and the Medieval Colonial Imagination (2014). Faletra's chapter "Crooked Greeks: Hybridity History and Gerald of Wales" works outward from Gerald's tentative suggestion and then denial that the Welsh language, and therefore the Welsh people, is derived from the Greek people:

Just as the correct name of the country is Cambria, so the people should be called Cymry or Cambrenses. Some say that their language is called Cymric, the "lingua Kambrica," from “cam Graecus," which means crooked Greek because of the similarity of the two tongues, caused by their long stay in Greece. This is arguable and possible, but I do not think it is the correct derivation. (Gerald, 1978, 232)

This, for Faletra, is evidence of Gerald's hybrid identity: his willingness to draw the Galfridian version of history into his own accounting of Welsh history set alongside his utter rejection of that synthesis. Faletra reads this not as a contradiction within Gerald's thinking, but as a piece of a larger strategy that frees him from teleological, colonial narratives such as those framed by Geoffrey of Monmouth's The History of the Kings of Britain, to which he indirectly alludes with this etymology (Faletra, 2014, 157, 172).

Faletra rightly argues that "history and hybridity" are intimately related in Gerald's work, although the meaning of Gerald's hybrids and how they relate to Gerald's own identity represent a more difficult set of questions to answer. Faletra's argument persuasively reads Gerald as "hybrid" in the sense that it is possible to impute a unitary identity out of seemingly incomparable perspectives, not unlike one of Gerald's marvelous "Irish" creatures that are single beings despite being composed of unlike components. Just such a reading about the stability of identity and the possibility of resolving the contradictions inherent within a being is at the heart of Caroline Walker Bynum's magisterial analysis of the nature of Gerald's hybrids in her Metamorphosis and Identity:

The hybrid expresses a world of natures, essences, or substances (often diverse and contradictory to each other), encountered through paradox; it resists change. (Bynum, 2001, 29-30)

Bynum uses some of Gerald's hybrids, particularly the werewolf, to advance her larger argument about the horror of mutability and the desire to preserve one's identity against change. Gerald's werewolves, who speak rationally and can pull back their skins to reveal their human forms, reassure the reader of the certainty that the "normal relationship between the interior and exterior" can be restored even after such a seemingly drastic transformation; they do not lose their identity (Bynum, 1998, 100). 
1 Gerald here appeals to St. Jerome's comments on phenomena in scripture that seem extraordinary: "[...] multa in scripturis incredibilia reperiri, nec verisimilia, quae nihilominus tamen vera sunt" [many things in scripture seem to be not credible which, however, are nonetheless true] (1897, 201).
While the creatures of Gerald's imagination can evade the loss of self, one wonders if this is possible for Gerald. His alternating desire to perform and subvert the expectations of his Welsh and Norman ancestry - much like his werewolf, one side is expected to be wild and violent, the other composed and civilized - seems to represent an irresolvable problem with identity. Gerald's stories about half-human creatures have been a channel for understanding not just Gerald's modus operandi as a historian, but the character of Gerald himself, a subject that even attracted the attention of a thirteenth-century audience to whose criticisms Gerald found it necessary to respond:

But it is no easy matter to act a counterfeit part and my critic, not being able quite to change his natural disposition, that he might at least do some mischief and vent the malignity with which he was bursting, he boldly cavils at the Second Distinction hoping that by convicting me of falsehood in that he shall discredit the whole. His objections are of this sort: the author he says "introduces a wolf talking with a priest; he draws a picture of a creature with the body of a man and the extremities of an ox; he tells us of a bearded woman; and of a goat and a lion which had intercourse with women (Gerald, [1863] 1968, 167).

Gerald calls upon the authority of Jerome, Augustine, Isidore of Seville, and Cassiodorus to support two claims: that a part of his work should not discredit the whole and that the hybrids that he describes should not be discredited for being "contrary to the common course of nature" (Gerald, [1863] 1968, 167). This defense stands in opposition to his critic's "not being able to change his natural disposition," an inflexibility that is completely unlike his hybrids, who can contain within themselves what is seemingly paradoxical, what he describes as "incredible" but nevertheless "true." 1

The marriage between the "incredible" and "true" offers an alternative perspective for reading Gerald's hybrids. Hybridity, for Gerald, signifies not just a set of biological peculiarities but, more importantly, the production of knowledge itself. As Gabrielle Spiegel argues in her work on medieval historical narratives, genealogy as a conceptual metaphor "governs the shape and significance of the past" (Spiegel, 1983, 48). However, when Gerald evokes other authorities as precedents for his own unbelievable creations, he does not seek to resolve the crux in meaning that the hybrid bodies - creatures with troubled or exceptional genealogies - represent within his work. Rather, he demonstrates the importance of the paradox as it inflects the work. He accedes that not even he can attest to the veracity of all that he reports. Gerald, with his typical sense of self-importance, suggests that the extraordinary in written histories should provoke his readers to wonder and should be left for posterity to explain. 
This presentation of his role as a historian recalls Gerald's description in The History and Topography of Ireland of a scribe miraculously able to reproduce intricate drawings presented to him by an angel (Gerald, 1982, 85). Gerald presents himself, like the scribe, as merely a tool to convey information that he did not generate, yet which he believes serves agendas that inhere within the book he creates. Indeed, Gerald's defense comes within the preface to his Expugnatio Hibernica, and in reference to his Topographia Hibernica; both purport to tell the history of Ireland but instead voice the colonial ambitions of the English over the Irish (Gerald, [1863] 1968, 166-168). His depictions of the Irish as grotesque and Ireland as home to monstrosity work in tandem with English military ambitions. Although the cultural work of his historical writing is clear, Gerald displaces his own participation in its creation and even his role as an interpreter of the details he provides. In doing so, Gerald calls into question the status of his historical writing. He abdicates any sense that it is possible for him to disarticulate the "incredible" and "true," suggesting instead that one opens up the possibility of seeing the other. He positions himself as merely an intermediary between what he reports and the uses to which his history might be put.

Franz Fanon deploys the term "colonized intellectual" to signify a hybrid subject who possesses a wealth of cultural tools within an intellectual system that limits and distorts the ways in which those skills can be deployed:

The colonized intellectual, at the very moment when he undertakes a work of art, fails to realize he is using techniques and a language borrowed from the occupier. He is content to cloak these instruments in a style that is meant to be national but which is strangely reminiscent of exoticism. (Fanon, 2005, 160)

The framework of the "colonized intellectual" allows for a critique that can explore the intimate relationship between Gerald as a thinker and Gerald's lived experience as Welsh. ${ }^{2}$ The vexed position of the "colonized intellectual," one who is dependent upon and at odds with a dominant political regime and its selfmythologizing, brings into focus Gerald's struggles with the influence of historical narratives that precede him, most significantly Geoffrey of Monmouth's History of the Kings of Britain. The Britons' desire for conquest in Geoffrey's History reads as a parable for the limitations of colonial ambitions. The Britons embark upon a campaign to conquer their sibling world power, the Roman Empire, which results in an apocalyptic end to their rule. As will be discussed below, Geoffrey reframes this conflict as a loss in the coherence of British identity and a failure of historical insight. This is signified by the conflict between powers that both make identical claims to supremacy based on their relationship to Troy and a complex lineage of military conflicts between the powers. Gerald's own histories on the Anglo-Norman conquests must engage
2 I use the term Welsh here mindful of the many caveats advanced by Robert Bartlett about the "intellectually confused, vague, and complex" issue of assigning regional identity through the "transparent but distorting curtain of modern nationalist thought.” (1982, 9, 10) However, I agree with his conclusion that while Gerald was certainly able to claim several identities because of his education and social standing, his relationship to Wales was the source of antagonisms and loyalties that would inflect much of his writing $(1982,12)$. 
3 As William of Newburgh puts it, "effraenata mentiendi libidine" $(1856,6)$. the powerful legacy of Geoffrey's work, while intervening in how the Welsh are presented as colonized subjects.

Gerald, writing in his Journey Through Wales, expresses his thoughts about the value of Geoffrey's history when describing the unfortunate condition of a Welshman, Meilyr, who was haunted by demons:

If the evil spirits oppressed him too much, the Gospel of St. John was placed on his bosom, when, like birds, they immediately vanished. But when the book was removed, and The History of the Britons by Geoffrey of Monmouth was substituted in its place, they instantly reappeared in greater numbers, and remained a longer time than usual on his body and on the book. (Gerald, 1978, 117-118)

Meilyr, because of the haunting, gained the ability to foretell the future and, despite being illiterate, could identify lies in books. This anecdote seems to be much in agreement with other later twelfth-century and early thirteenth-century historians who accused Geoffrey as having an "inordinate love of lying" (William of Newburgh, 1856, 6, my English translation). ${ }^{3}$ However, to read it this way would ignore the broader expression of the potential for Geoffrey's work to influence its reader. Meilyr is oppressed by the presence of demons around him, yet he is able to employ that malady to practice virtue and spot transgressions in the men of faith around him. Like the unfortunate Welshman swarmed with demons, Gerald's oeuvre is shot through with Geoffrey's influence despite the former's stated resistance to the "fabulous history" (Gerald, 1978, 232). Gerald critiques Geoffrey's fanciful inventions in the midst of his own colorful fictions; he simultaneously tries to separate himself from and follows in the footsteps of Geoffrey. The project of separating his intellectual heritage and his own critical lens becomes tangled when Gerald turns to the Anglo-Norman colonization projects in Ireland, wherein he makes use of the Galfradian version of British history to explain the patterns of conquest on the island. The tension between the two urges is at the heart of my deployment of the term "colonized intellectual." To understand Gerald and his approach to writing history, he must be read through the competing and contradictory impulses that are at work within his writing.

The use of postcolonial theory to read how Gerald's historical writing is encoded constitutes a vibrant thread within studies of the writer. Notably, in the volume The Postcolonial Middle Ages, Jeffrey Jerome Cohen draws on border theory to understand Gerald's conception of homeland in The Itinerary of Wales. This line of inquiry allows Cohen to analyze Gerald as a writer whose work is vexed by conflicts between his identity as a Welshman, as a representative of the Church, and as a subject hoping to ingratiate himself with the English crown. He describes Gerald's writing as characterized by "competing allegiances conjoined with tortured abjections” (Cohen, 2000, 87); Gerald 
writes about the subjection of his own land alongside discourses about how the land might be kept under English rule (Cohen, 2000, 87). The Welsh borderlands, according to Cohen, have a metonymic relationship to Gerald's own intermediate status between native Welsh rule and rule by Norman lords; the Welsh marches become a space through which to read Gerald's own difficult identity.

Cohen chooses not to investigate the postcolonial implications of The Itinerary of Ireland and The Conquest of Ireland because he considers them to be "reductive texts that unabashedly glorify the invasion of the land, demonstrating none of the conflicted identifications characteristic of the Welsh texts" (Cohen, 2000, 85). Cohen's assessment of Gerald's work on Ireland is hardly new; sharp and spirited criticism has followed Gerald's work for hundreds of years, as exemplified by Gerald's response to the unnamed contemporary cited above. ${ }^{4}$ These perspectives on Gerald's work about Ireland revolve around how he interposes fiction within what is ostensibly history to explain the constellation of English power, Irish subjection, and Welsh intercession between these sides. However, the divisions between the colonizer and colonized are far more troubled than he or his critics often allow; the descriptions of Ireland reveal a person at odds with himself about the place of his intellectual labor within the colonizing process, and more generally how to reconcile the mythical history of the Welsh as the once and future rulers of Britain with their present role working under the English crown to subjugate Ireland.

Ireland, for Gerald, is a cathected space; it represents the intersection of his literary ambitions, his political aspirations, and his ever-present knowledge of Welsh oppression. In writing about the land, he cannot help but tie Ireland's political fate to his own success and the fortunes of the Welsh people. One can glimpse the intimate connection between Gerald's Ireland and Gerald himself from his Autobiography, in which he discusses his goals for writing The Conquest of Ireland. This assessment comes after Gerald refuses to become the bishop of either of two bishoprics in Ireland offered to him by John, son of King Henry II. Although Gerald desired the authority a bishopric would afford, he believed that John had no intention of actually improving the status of the church in Ireland. In contrast, he saw the writing of Ireland's history as a project that would grant him a measure of gain external to that offered by political or religious appointment:

Seeing that the Earl made no advance toward that end, but that the state of Ireland was every day the worse for his coming, and considering the many strange and notable things that he [Gerald] observed in that country, things found nowhere else and utterly unknown, he set himself with great zeal and diligent inquiry to collect materials first for his Topography and then for his Conquest of Ireland, that he might at least by his own labor win some profit or conquest [conquestum]. (Gerald, 1937, 90)
4 For a list of criticisms of Gerald's work on Ireland see Giraldi Cambrensis Opera ([1867] 1964, lxxv). 
Gerald here refuses the type of advancement for which he spends much of his life longing, that is, to move upwards in the Church hierarchy beyond archdeacon. When he sees those ambitions frustrated, he still seeks to direct his intellectual labor towards not only extracting from Ireland, but also asserting some dominance over the island through writing its history. The word conquestum is a pivotal word for Gerald in the context of Ireland. Conquest becomes a term that oscillates between the physical and the literary, the historical and the personal. (Indeed, not only does this word appear here, but also in the questions of conquest and profit shot through Geoffrey of Monmouth's work.) His Expugnatio Hibernica locates Gerald's family among the primary actors behind the conquest; his literary work is part of his family business and his personal fortunes are joined with those of Ireland. He would claim in his first preface to the Expugnatio Hibernica that the train of events of the conquest were in themselves unpromising - "narrow, barren, rough and unprofitable" - before he brought his artistic powers to bear on them (Gerald, [1863] 1968, 171). Writing the history of Ireland functions as an attempt to constrain the potential meanings of Ireland's conquest and also as an act of selffashioning that redefines his own subject position. In working through both the histories of the Welsh and the Irish, Gerald finds himself in the contradictory position of being both the colonizer and the colonized.

Gerald's work presents an ideal opportunity to engage in the project of reconceptualizing postcolonial temporality. This work is incumbent upon medievalists; when one reads Christopher Columbus' diary or Spenser's A View on the Present State of Ireland in relation to Mandeville's Travels or Gerald's The History and Topography of Ireland, the debt these colonial texts have to the Middle Ages is quite clear. To read the medieval within the postcolonial "undermines the edifice of colonial modernity"; that is, the Middle Ages trouble the identification of the postcolonial with the modern and suggest a critical revision of the structures that directly functioned as colonizing forces (Ingham and Warren, 2003, 3). Gerald's Conquest of Ireland and History and Topography of Ireland provide several nuances to this general project. By associating his histories of Ireland with Geoffrey's History, he makes a set of historiographical and narratological claims. Gerald wields The History of the Kings of Britain's movement towards salvation and the promise of a future social domination for the Britons as a narrative framework for his own personal and familial conquests made visible by a critical reassessment of the past. At the same time, he keeps in view the contrasting perspective of the Irish as having the ability to mobilize those self-same narratives. Such choices about narrative frame matter in colonial and postcolonial contexts (Scott, 2004, 7). Gerald uses them as part of his literary intervention, as a way of keeping dominant and subordinate perspectives in suspension. Gerald's work demonstrates that the Middle Ages were not simply an antecedent to early modern theories of nation. Rather, the Middle Ages contain within themselves a set of competing and 
shifting temporalities with pasts that were continually being recreated to mediate desires for origins, for futures, and for conquest.

\section{Geoffrey of Monmouth and The Conquest of Descent}

[Genealogy] operates on a field of entangled and confused parchments, on documents that have been scratched over and recopied many times...the world of speech and desires has known invasions, struggles, plundering, disguises and ploys. From these elements however, genealogy retrieves an indispensible restraint: it must record the singularity of events outside of any monotonous finality. It must seek them in the most unpromising places, in what we tend to feel is without history - in sentiments, love, conscience, instincts; it must be sensitive to their recurrence, not in order to trace the gradual curve of their evolution but to isolate the different scenes where they are engaged in different roles. (Foucault, 1984, 76)

Genealogy, in the many senses that Foucault evokes, is a critical subcurrent to The History of the Kings of Britain and the works that are inflected by it. ${ }^{5}$ Not only is genealogy the operating logic of Geoffrey's text, as it purports to tell the complete line of succession of British kings, but Geoffrey even constructs an intellectual heritage for his history. He claims to merely translate a "certain very ancient book in the British language," which situates his text as the latest version in a chain of histories that have their origin in an oral tradition (Geoffrey, 2008, 41). But the genealogy that Geoffrey constructs is not at all the "orderly and unbroken" chain of events he purports to tell (Geoffrey of Monmouth, 2008, 41). Indeed, it is doubtful if there was even an "ancient book" from which he derived his text (Shichtman and Finke, 1993, 8). This claim of a fictional source, while a common trope in medieval historiography, is an informing context for the numerous misdirections that inflect Geoffrey's work (Echard, 1998, 34). What appears to be translatio studii, the work of a colonizing power being exercised over a British history, is really a demonstration of Geoffrey's abilities to invent his own authorities. This is a radical interruption in an orderly chain of histories about Britain, particularly as Geoffrey claims that he could not glean enough from the likes of Gildas and Bede. This suspicion of linearity is mirrored by the larger structure of the history itself. Discontinuities abound within the history's movement towards religious salvation in the forms of "invasions, struggles, plundering, disguises and ploys" (Foucault, 1984, 76). Ruptures in the clarity of lineage and succession challenge the history's logic as a fungible reading of the past. Rather, the text presents the pitfalls of overlooking the complications and breaks in historical material and the logic of genealogy.

The paradoxes of genealogy and conquest are nowhere more apparent than in the Arthurian section of the History. Until this point of the narrative, Rome is a foil for Britain, a more advanced power against which the country measures
5 Gerald was by no means the only writer during the twelfth and thirteenth centuries to struggle within the umbra of The History of the Kings of Britain. William of Newburgh, William of Malmesbury, Walter Map, Wace, and Layamon found themselves confronting the legacy of Geoffrey, either directly through disparagements of Geoffrey's fidelity as a historian or obliquely through stylistic borrowings or adaptations of his work. 
itself. The rivalry with Rome that simmers throughout the text ensures that the memory of Troy, their mutual point of origin, is never far out of view. However, when Arthur reaches the height of his powers, having consolidated his rule over Britain and expanded his control over much of Western Europe, his empire begins to not only challenge but to resemble that of Rome. The ensuing war between the two countries represents a crux in lineage that the text never resolves. As tensions between the powers simmer, one of Arthur's vassals, Augusel, expresses his eagerness for the war against the Romans in cannibalistic terms, the irony of which he fails to grasp:

I thirst for their [the Romans's] blood, as I would thirst for a fountain if I had been forbidden to drink for three days. O, let the light shine upon me, the light that will be the sweet wounds that I will either receive or mete out when we exchange blows in battle! Even death will be sweet when I endure it to avenge our fathers, to protect our liberty, and to exalt our king. (Geoffrey of Monmouth, 2008, 180)

As Geraldine Heng instructs in her study of The History of the Kings of Britain, strict attention must be paid to Geoffrey's presentations of cannibalism. She links the references to anthropophagia to the traumatic history of British attempts at conquest in the First Crusade (Heng, 2003, 35). In the scene above, Augusel's extreme response calls attention to the fact that the blood the knight thirsts for is the blood of his relations, and his desire for it suggests a profound misunderstanding of the historical rapport between the two sides. His imagery not only anticipates the apocalyptic end of Arthur's rule, but also the monstrousness of its fratricidal nature.

What precipitates Augusel's response is the arrival of messengers from Rome who demand tribute, the monetary acknowledgement of subjection (Geoffrey uses the verb subiogare), from Arthur. The king refuses and gathers the members of his court to debate his course of action. Before he makes his decision, he reviews the history of Britain's political relations with Rome:

He claims that it should be given to him because it had been paid to Julius Caesar and his successors, who came here in armed force because of our forefathers' disputes, and who had once subdued our fickle and quarreling homeland to their power with force and violence. Since they had obtained the tribute in this manner, they took it unjustly indeed. Nothing that is acquired by force or violence can be justly possessed by anyone. Since he presumes to make these unjust demands upon us, let us use a similar tact and demand tribute from Rome. (Geoffrey of Monmouth, 2008, 178)

Arthur continues to enumerate the number of British kings who have conquered Rome in "ancient times" (Geoffrey of Monmouth, 2008, 178). Arthur here is doing the work of a historian; he reviews precedent and sees himself in line with 
the tradition of the other three kings who have overtaken Rome: Belin, Constantine, and Maximilian. Through these kings, he believes that Rome should offer him "vectigal," tribute, or profit (Geoffrey of Monmouth, 1957, 166-167). Even in what should be a crucial moment of self-definition that separates the two powers, Geoffrey presents their dispute in ways that only highlight how closely they mirror one another. Arthur acknowledges that the reasoning the Roman emperor Lucius employs to demand tribute is a "flimsy pretext," yet he chooses to apply the same thinking towards the Romans (Geoffrey of Monmouth, 2008, 178).

Arthur constructs a linear narrative across these genetic and historical links. This version of the past strips away the joint ancestry of Rome and Britain via Troy and ignores their more proximal ties, on view when the Romans welcomed the British King Constantine into Rome and when the Britons wept at Roman abandonment of the island because of constant British mismanagement (Searle, 1988). ${ }^{6}$ Arthur draws his lineage along a line of strife in British history. He chooses exceptional moments when Britain is actually at its least British: when it seeks to expand, to conquer other lands, when its identity is thoroughly international. He locates moments of rupture, during extraterritorial invasion when the Britons begin to lose the clarity of national identity as defined by the island, and identifies those moments as the train of lineage leading up to Arthur's own time and situation. Arthur chooses his ancestors and sheds others to refine the idea of Britishness. Arthur "preach[es] the restoration of memory, he practices the science of forgetting” (Roach, 1998, 109).

The text suggests that Arthur's version of history should be treated with some skepticism. Although Arthur does defeat the Romans in their initial engagement, the victory only demonstrates a misjudgment of the issues at stake. While he argues that conquest will allow the Britons to recapture ancient claims, his foreign incursions fundamentally undermine the political foundations of Arthur's rule. The British army sustains heavy losses, and Arthur's nephew fills the void in power by seizing the throne and marrying Arthur's wife, Guinevere. These violations, particularly the latter, which Geoffrey describes as Mordred's "wicked pleasure," are signs of genealogical and successional confusion (Faletra, 2008, 196; Warren, 1998, 118). After what is meant to be a conclusive expression of British might against the Romans, Arthur's progress towards Rome is halted by the need to address Mordred's usurpation. This is to say, at the point of the greatest outward extension of British power, the lines of succession fracture in Britain and a civil war ensues.

The Arthurian section of the History "witnesses [a] subtle negotiation of multiplicity that both supports and resists superior powers" (Warren, 1998, 108). While Arthur's efforts at consolidating power are treated with admiration, the slide into empire is read as unsustainable. The totalizing narrative that Arthur seeks to weave for the Britons about their own military supremacy is
6 Searle (1988) describes the concept of fictional kinship during the Norman period, in which fictional connections and even fictional stories about ancestors were created to strengthen one's genealogical pedigree. 
7 See the review of the many and varied medieval and modern reactions to Geoffrey's work in Flint (1979). undone by the metanarrative of the History, which is marked by disjunctures and unlikely political allegiances. As its long critical tradition attests, The History of the Kings of Britain provokes anxieties about the nature of the histories within it, and perhaps the project of writing about the past in general. ${ }^{7}$ However, to create such a destabilizing perspective, Geoffrey casts the Britons as given to war and eternally waiting for the return of Arthur. The History of the Kings of Britain and its presentation of the Britons' certainty of history's teleological arc become an informing text and context for Gerald of Wales. Although Geoffrey's work lacks the paternity it assumes in its "Dedicatory Epistle," it still leaves an intellectual bequeathal Gerald must transume when he tries to write his own narratives of conquest.

\section{Gerald's Ambivalence}

Colonialism is not satisfied with snaring the people in its net or [with] draining the colonized brain of any form or substance. With a kind of perverted logic, it turns its attention to the past of the colonized people and distorts it, disfigures it, and destroys it. (Fanon, [1963] 2005, 149)

The most prominent example of how heavily being a descendent of the Britons weighs on Gerald comes in his autobiography. During an audience with Pope Innocent III, the pontiff has a letter from one of Gerald's adversaries, the Archbishop of Canterbury, read aloud. Its text is a bitter invective against Gerald, based largely on his connection to Wales:

[... Gerald] would thus to the best of his power sow the seeds of perpetual dissension between the Welsh and the English for all time to come. For the Welsh stock of the Britons, boast that all Britain is theirs by right. Wherefore, if the barbarity of that wild and unbridled nation had not been restrained by the censure of the Church, wielded by the Archbishop of Canterbury, to whom it is known that this race has thus far been subject as being within this province, this people would by continual or at least by frequent rebellion have broken from their allegiance to the King, whereby the whole England must have suffered disquietude. (Gerald, 1937, 169)

For Gerald, genealogy is not a thing of the past, or something that may be overcome through his learning. Rather, his place of birth and his heritage are living with him and never far from informing his present. However, it is not enough to simply say that others' perception of his heritage was sufficient to map the course of Gerald's life, or that this is the sole angle of refraction through which Gerald observes his life. Rather, his intervention and conception of his position with respect to his heritage are, as Foucault describes, multilayered - a collocation of mythmaking, family history, and Gerald's own historical circumstances. 
This complex situation motivates much of Gerald's intellectual work, and generates the "competing allegiances" and ambivalences to his own actions. The "distortions" (per Fanon) of Welsh history derived from The History of the Kings of Britain hold tremendous sway in Gerald's life. They operate as part of the force of subjugation that render Gerald "known" in the sense that he cannot break completely free from the narrative structures in place around him (Fanon, [1963] 2005 , 2). However, he in turn recognizes the power of this type of intellectual work and uses its force against the Irish to renegotiate the hierarchy of Anglo-Norman society. Gerald uses his writing as a literary conquest while he keeps in perspective his own position as a colonized subject. For Fanon, to be a colonized intellectual is to be "the living focus of contradictions" whose education and set of values learned under a colonizing force chafe against lived experience. When thinking of the close relationship between the colonist and the colonized, Fanon writes: "The colonist and the colonized are old acquaintances. And consequently, the colonist is right when he says he 'knows' them" (Fanon, [1963] 2005, 2).

What Gerald has to offer King Henry is his intimate knowledge of Ireland. However, this knowledge creates an intellectual quandary for him from which he never quite emerges. The monstrous tones with which Gerald paints the Irish redound to an exoticism that he seems to apply to himself. Critics of Gerald are right to see him as painting Ireland as available for conquest. However, it is necessary to complicate this perspective by understanding that conquest for Gerald is not an unalloyed good. Rather, conquest has the potential to erase both the coherence of the invading force and the nation being colonized.

It is difficult to underestimate the lengths to which Gerald goes to depict the Irish as monstrous, particularly in terms of their relationship to genealogy. In The History and Topography of Ireland, he organizes his topography in three sections. Roughly, the first section describes Ireland's flora and topography, the second its fauna, and the third its people. However, there is substantial overlap between each of these sections, and between the categories that Gerald sets up. The hybrids that his critics found so detestable particularly create problems with these divisions. The monstrosities of Gerald, the half-human creatures or the Irish who have a penchant for having sexual relations with animals, frame the Irish as an underdeveloped people held outside of time by their regressive sexual habits. Gerald underscores this with a long invective against the Irish, which ends with the accusation that they regularly commit incest:

Moreover, and this is surely a detestable thing, and contrary not only to the Faith but to any feeling of honour - men in many places in Ireland, I shall not say marry, but rather debauch, the wives of their dead brothers. They abuse them in having such evil and incestuous relations with them. In this (wishing to imitate the ancients more eagerly in vice than in virtue) they follow the apparent teaching, and not the true doctrine, of the Old Testament. (Gerald, 1982, 106) 
His accusations of Irish sexual deviance imply that the clear progress of generations and of faith is stunted on the island. What is yet more remarkable about this passage is that Gerald claims to have delivered these remarks during a sermon before Irish clergymen as well as clergy from Wales and England to Ireland (Gerald, 1937, 91). The sermon's topics encompassed the "vices and excesses" of the Irish prelates, namely "drunkenness," "carelessness," and "negligence of pastoral duties" (Gerald, 1937, 92). Gerald is sure to note that his stinging critique is a decisive victory for "our clergy": "the Irish clergy were covered with much confusion, while ours lifted up their heads, insulting their foes and exulting in their own victory" (Gerald, 1937, 96). Gerald envisions the Irish clergy as a degraded version of the Welsh and the Anglo-Normans, a rhetorical strategy that allows him to elide the differences between the latter two groups and offer himself as a proxy for both.

His treatment of the Irish bears comparing with the way that Gerald presents his own suitability to lend King Henry II's son, John, advice for how to bring about Ireland's full subjugation. Gerald humbly describes his own qualifications: "he had a great host of kinsmen there, sprung from the first conquerors of that nation and because he himself had shown himself to be an honest and prudent man" (Gerald, 1937, 86). The clarity of his familial connections and his own personal virtue stand in contrast with his presentation of the Irish. This quotation brings into focus the careful negotiation that Gerald engages in to present himself as distinct from the Irish - with even some hereditary claim to rule - while also the ideal servant to the crown because of his intimate knowledge of them. His attempts to work between these two positions fail. John listened to "the counsel of young men he took with him" instead of Gerald, and he "rebuffed the honest and discreet men of the country, treating them as though they had been foreigners and of little worth" (Gerald, 1937, 87). These critiques chime with the very qualities that Gerald holds as so valuable to the mediating role he carves out for himself within the occupying force. Gerald neither fits as a close confidant of John nor as a native informant.

John is unable to make any inroads into consolidating British power over Ireland and he leaves. However, Gerald does not return to Wales; he chooses to begin writing his histories of Ireland. He "remained in the Island to the following Easter, that he might pursue his studies more fully, not merely gathering materials, but setting them in order" (Gerald, 1937, 91). Gerald's claim that he will set the information he gathers "in order" distantly echoes Geoffrey of Monmouth's promise of an "orderly and unbroken" history. The project of physical conquest is simply replaced by intellectual conquest. Indeed, as noted above, conquestum is the word Gerald himself uses for his labors. Although the circumstances have changed because of John's departure, Gerald's calculus remains the same. He offers what he sees as his innate knowledge as a descendant of the Britons and his learning gained from traveling through Ireland 
as a way of consolidating his authority to over Irish history, which he can offer to a wide audience for his advancement.

At this intersection of Gerald's genealogy and his learning, his eagerness to prove himself betrays a more complicated set of ties between the Welsh and the Irish. For example, Gerald argues that the Normans are ill-equipped for a campaign in Ireland because of their reliance on armor (a strategic weakness against the lightly armed Irish, who would be more nimble) and, more impressively, because of the Normans' dependence on being near reliable sources of wine, as "the Normans could not do without wine, having been used to plenty of it from their youth" (Gerald, [1863] 1968, 320). Gerald suggests that the Welsh, in contrast, are well adapted to what it would take to properly execute a campaign in Ireland:

In all expeditions, therefore, either in Ireland, or in Wales, the Welshmen bred in the marches, and accustomed to the continual wars in these parts, make the best troops. They are very brave, and from their previous habits, bold and active; they are good horsemen and also light of foot, being equally suited to both services; and they are not nice in their appetites, and bear hunger and thirst well when provisions are not to be had. (Gerald, [1863] 1968, 320)

This description of Welsh strengths is curious because it does some of the same exoticizing work that Gerald does when he categorizes the Irish. The Welsh need to eat less, are physically capable of negotiating Ireland's terrain, and can execute sustained military campaigns because of the distorting effects of "continual war." He positions the Welsh as like the Irish, molded in similar ways by their interaction with the land around themselves and the violence tracked across it. The work of conquest and colonization becomes the common ground between them.

Gerald connects the Welsh with the Irish on the basis of conquest itself; the history of being subjugated is part of a shared past and is a parallel motivation for them. Gerald records a dispute he had with Rhys ap Gruddydd, Prince of South Wales, that demonstrates the slippage between the meaning of the Welsh and Irish struggles against subjugating powers. Gerald sets the scene carefully. He mentions that when he meets Rhys in Hereford, he is seated between William De Vere, the Bishop of Hereford, and the Baron Walter FitzRobert, both of whom, Gerald mentions, are of the house of Clare, that is, from Norman families. Gerald gently goads all three men by mentioning that Rhys had just "recovered" possession of Cardigan away from Roger, the Earl of Clare, an understated description of a revolt against King Henry's forces. ${ }^{8}$ None of the men rise to this barb. They choose instead to compliment each other on having

8 See Gerald (1982, $82)$. won and lost land "not at the hands of sluggards of obscure birth, but to men of such high fame and renown" (Gerald, 1937, 82). Some time later, Gerald tries again, wondering aloud why Rhys's family had not sought to extend their 
conquest beyond the South of Wales. This provokes a sharp retort from Rhys about the involvement of Gerald's family (the descendants of Nest) in the conquest of Ireland, before the important men assembled and the king's messengers:

Now since these things were said before a large audience, in the presence of the Archbishop and Justicar and the Bishops also and Barons who by now had joined them in considerable numbers, for a brief space Rhys blushed for shame, but being a wise and discreet man, he answered in the same fashion, saying that in truth the descendants of Nest were, both then and now, good men and courageous, and that they had made a great conquest in Ireland, if they could only be sure of keeping what they had got. Now he added this last sally, because these two nations, the Welsh and the Irish, fed continually on the hope of recovering all the lands which the English have taken from them. (Gerald, 1937, 198)

Gerald stages this spat to force Rhys to reveal his own desire to continue his campaign against the British King. He hopes that word of this will get back to Henry and remind the king of Gerald's loyal service when he "turned aside not a few of Rhys's great armies from the king's land" (Gerald, 1937, 84). In the end, although Gerald believes that the king hears of this news, Gerald's advancement is still thwarted because of his "nation and his kinship" (Gerald, 1937, 85).

This exchange between Gerald and Rhys and Gerald's own meditation on the king's nonresponse shows, writ small, the many competing interests that Gerald contains within himself. Gerald is slow to realize what Rhys already seems to know. Gerald is at pains to establish the distance between himself and the Welsh, particularly the rebels. He uses this opportunity to underscore that his family's assistance in the conquest of Ireland was firmly in the favor of the king's forces. Rhys's response, which is teased out by Gerald, is an unexpected one. It ties the fate of the Welsh, and their mythological connection to the ownership of Britain, to the current situation of the Irish; Rhys's reply suggests that the Irish and Welsh struggles are similar in their unending concern for the restoration of lands. Moreover, Rhys exposes the inherent contradiction in Gerald's pride about his own achievements, which rests heavily on his family's nobility and the deeper Welsh connection to the august lineage of Trojans. In working to aid the king's conquests, Gerald is betraying the very things that he claims make him so well suited for that mission. He is submitting to the king, rather than resisting, which, as Rhys argues, is a reaction incumbent upon the Welsh as it is upon the Irish.

Gerald of Wales seems to become aware of the contradiction of his position. Repeatedly passed over for advancement by the king as well as the Church hierarchy, he wonders why his ploy to remind the king of his family's service generates no tangible results. He receives "empty praise and flattery and great promises of future reward” as his only payment for his loyalty (Gerald, 1937, 
84). Throughout his Autobiography, he records requests for favor, without ever seeming to directly address the dissonance between his actions and his reward. The language of the competing drives for whatever power can be afforded to him and his resentment at being in such a submissive position seems to elude Gerald. Rather, it is within the realm of his intellectual pursuit, his own literary "conquest" of Ireland, that he seems to have space to begin to unpack this problem.

Through the work of history writing, he is able to elucidate the contradictions of his family's position under the colonial power of the British. Gerald's understanding of conquest mythology, so readily on display throughout his writing on the conquest of Ireland, undergirds his historical analysis of both the Irish and the Welsh. Gerald is able to fluently read the story of the Brut derived from Geoffrey of Monmouth's History of the Kings of Britain into the conquest of Ireland; he goes so far as to justify the British right to rule over Ireland in part by making recourse to Geoffrey's History (which he simply calls "the British history"). Gerald recounts the story of King Gurguntius's conquest of Ireland and Arthur's later recapturing of the land:

[W] have the testimony of the British history, that Gurguntius, the son of Belinus, and the King of Britain, on his return in triumph form Denmark, met the fleet of the Basclenses at the Orkney Islands, and set them forward to Ireland, giving them pilots to direct their course thither. The same history informs us also that Arthur, the renowned king of Britain, had kings of Ireland tributary to him and that Gillomarus, king of Ireland, with other kings of the isles, came to his court of Caerleon (Gerald, [1863] 1968, 262).

One contemporary editor of The Conquest of Ireland found this line of reasoning a way to "gloss over the injustice of King Henry's pretensions to the domination of Ireland" and "too puerile to merit a single comment" (Gerald, [1863] 1968, 263). And indeed, here Gerald acts as a historical interpreter and advisor to the king. He shows no marked difference in sentiment than when he goads Rhys. However, to dismiss the use of British history throughout the text is to miss the flexibility of the narrative.

The Brut narrative proves to be versatile enough to be used by both the conquering Welsh and the resistant Irish. Roderic O'Conner, the Irish prince of Connaught, makes use of Geoffrey's history to rally his forces against the king's army, particularly those led by Gerald's uncle Fitz-Stephen:

For to satisfy his insatiable malice in the blood of his own people, he spares neither himself nor his country, nor sex, nor age. This is he who formerly was a most cruel tyrant over his own subjects; this is he who, supported by a band of armed foreigners, is preparing to revel in the blood of us all. $\mathrm{He}$ [Fitz-Stephen] deserves therefore to be treated as a public enemy, who 
proves himself to be the enemy of all. Mark, my countrymen, mark well, how most states have been overthrown in this way; I mean by civil discord. Julius Caesar, after having twice shown his back to the Britons, returned a third time, and subdued the country on the invitation of Androgius, who was a victim of his own thirst for revenge [...] To come to examples nearer to home, and our own times, we find Gurmund the terror of the isles, bringing in the Saxons for the subjugation of the Britons, though it turn out to his own ruin and humiliation (Gerald, [1863] 1968, 198).

It should be underscored how readily Gerald casts Roderic in the position of the British in The History of the Kings of Britain; the Irish are poised to be overcome by foreign invaders who will end a tyrannical reign. Moreover, the myth can be extended to encompass the Welsh themselves. Those who should be the inheritors of Britain are cast as the great traitors of the nation. Perhaps most damningly of all, Roderic's language about Fitz-Stephen's “insatiable malice in the blood of his own people" recalls the language of blood thirst in Geoffrey of Monmouth. Roderic offers a sophisticated reading of the "British history" that frames the Welsh as trapped within this narrative that they hold so dear, unable to evade its pitfalls. Particularly, Roderic highlights Arthur's desire to conquer Rome, which fundamentally alters the integrity of the British state. Roderic emphasizes that the Welsh are betraying more than just the Irish. In following Fitz-Stephen, Roderic argues that the Welsh may be following the same path to becoming unrecognizable to themselves.

Gerald does not stop at adding this one wrinkle or inversion to the use of the Brut narrative. He contrasts Roderic's speech with that of Fitz-Stephen to set up a dueling interpretation of the mythical past. Fitz-Stephen begins by discussing the blood of the Trojans, using language similar to that which Gerald deploys to discuss the Welsh superiority in arms. However, Fitz-Stephen then broadens the discussion from genealogical inheritance to Welsh land claims:

We derive our descent, originally, in part from the blood of the Trojans, and partly we are of the French race. From the one we have our native courage, from the other the use of armor. Since then, inheriting such generous blood on both sides, we are not only brave, but well armed, can it be supposed that an unarmed multitude and mere rabble are able to resist us? Recollect, besides, that we have left behind in our native land ample patrimonies which we lost through domestic frauds and internal mischiefs. Wherefore, we are come hither, not for the sake of pay and plunder, but induced by the promise of towns and lands, to be granted to us and our heirs forever. (Gerald, [1863] 1968, 200)

Although Fitz-Stephen, like Roderic, evokes the significance of recalling the history of the island's possession, his inflection is different. Fitz-Stephen takes on the mantle of the colonist, picking up the desire for movement and conquest that 
is in keeping with the actions of Geoffrey's Britons. This speech echoes that of Arthur talking about Rome as Britain's inheritance and rightful territory. And just as was the case in Arthur's rhetorical push to war, Fitz-Stephen is adept at combining the logic of conquest with the manipulation of dubious historical claims.

Between Roderic and Fitz-Stephen pass a dense set of competing uses of myth, layered over one another in Gerald's history. These uses defy the argument that Gerald focused his work on Ireland solely to dehumanize the Irish and trumpet war. Rather, his work makes more sense within the idea of the colonized intellectual, Fanon's idea of the man whose conflicting senses of belonging expose themselves within work that has another apparent aim. Gerald's histories are a nest of contradictions. He wished for his writing to reach a wide and popular audience, in the sense of being able to be understood by as many people as possible. Yet, Gerald is at odds with the language he uses to write The Conquest of Ireland. In the second preface to the work, he requests that "some man of learning" translate it into French. He even expresses jealousy that his friend, Walter Map, gained fame through his great eloquence of speech. However, Gerald consoles himself with the knowledge that his works will be recovered in posterity (Gerald, [1863] 1968, 177-178). He paints a strange portrait of the Welsh, as both the willing hands of the Irish conquest, and as a people worthy of independence. Tied to this sense of Welsh duty is his own indignation at how poorly the Welsh, particularly his own family, have been rewarded for their services to the crown, which bubbles over at times in The Conquest of Ireland:

For this seems to have been the fate of the whole of this race. In all services of war they were highly valued; always in the van, they were eminent for their valor and daring in every noble enterprise; but as soon as the occasion for their services had ended, they were neglected and treated with utmost contempt. But malice itself could not succeed in extirpating this generous race, so that even to this day the family, putting forth new branches, possesses no small share of wealth and power over the island. Who first penetrated into the heart of the enemy's country? The Geraldines. Who kept it in submission? The Geraldines. Against whom are the shafts of malice chiefly directed? The Geraldines. Oh, that they had found a prince who could have justly appreciated their distinguished worth! (Gerald, [1863] 1968, 274)

Here, Gerald is unable to resist putting his family, the Geraldines, at the center of his vision of the conquest. Simultaneously, there are slight overtones of the Welsh longing for a great leader, just as Geoffrey of Monmouth writes about the longing for Arthur's return. The narrative of the nation and Gerald's own selffashioning are interlocked in Gerald's mind; he uses one to shape and redefine the other. The betrayals of the English fit into the larger pattern of intrigues and 
political mistrust that has plagued the Welsh since the end of the height of their power.

As he draws The Conquest of Ireland to a close, Gerald uses a quotation he attributes to Evodius, but which would function well as an epigraph for his whole work: "Past ruin gives a lesson to future generations, and former mishaps are a caution ever afterwards" (Gerald, [1863] 1968, 324). He quotes this as part of a list of suggestions for how the English can best govern the Irish. His ideas vary from erecting additional fortresses in Ireland, to banning the Irish from carrying axes, to nominating fair-minded judges to the preserve the rule of law. He ends the list with the suggestion that the Irish pay tribute to the British crown, either in the form of money or birds:

Thus, as time proceeds on its course, and the regular line of descent is perpetuated to its furthest degree, this annual tribute should be retained, as a lasting acknowledgement of this conquest, in the place of a written instrument, to the British nation [Britannici] and king. (Gerald, [1863] 1968, 324).

This is a curious note for Gerald to sound at the end of a text about his own ancestors' work of conquest. In a final set of contradictions, Gerald shows deep skepticism about the ability of a written record, particularly his own, to properly attest to the events of the past, while he simultaneously entertains considerable faith in the prospect of lineal descent. And perhaps most strangely he seems to withdraw his call for the Irish to be completely submissive to the Welsh. The divisions of people he outlines in the text - the English [Angli], the Normans [Normanni], or the Welsh [nostri, as Gerald often writes] - do not mark his final vision for the rulers of Ireland. Instead, he uses "Britannicus," a word that he employs rarely, but which suggests a vision of rule and of nation that supersedes those other divisions. While this is an understated concession from Gerald, it is significant insofar as it shows that, to the end of the text, Gerald is still searching for a coherent national identity through the space of Ireland.

While there are limits to applying the theories of a modern political thinker to the products of a far distinct age, the term "colonized intellectual" lends some reason to a text that threatens to be baldly inaccurate during its best moments and toxic at its worst. Fanon uses "colonized intellectual" to evoke a writer trying to find the idiom in which to describe the nation. He outlines the long, furtive, and often failed process of the colonized intellectual to situate him- or herself within the new realities of a decolonized political situation. While attempting to understand Gerald's inward gaze - his desire to rationalize the place of the Welsh and himself within the spheres of the King Henry's court and the church - does not undo Gerald's complicity in the colonizing project, it does nuance Gerald's writing. Gerald's contradictions paint a portrait of a writer trapped in the ironies of his work. Beneath what Gerald would present as the 
biological and dispositional differences between the Irish and normative humanity (i.e., that the Irish are untrustworthy and monstrous) are the historical similarities that Gerald cannot suppress. Gerald is caught in the paradoxical role of being both colonizer and colonized, a situation that is embedded within the history that Gerald uses as his guide. The past is oracular for Gerald, and he believes it to be the key to validating his personal sacrifices for Britain. What seems to elude Gerald are the far-reaching consequences of his intellectual uncertainty, the ripples his work would cause beyond satisfying his personal ambitions. His writing on Ireland, and his quest for distinction, would create an intellectual template for imagining the Irish that would be repeated for hundreds of years, through ages and countries he could not possibly have envisioned.

\section{About the Author}

Matthew Vernon is an Assistant Professor of English literature at the University of California, Davis. He is currently working on a monograph about medievalism and the construction of black identity in the nineteenth century (E-mail: mxvernon@ucdavis.edu).

\section{References}

Bartlett, R. 1982. Gerald of Wales: 1146-1223. Oxford, UK: Clarendon Press.

Bynum, C.W. 1998. Metamorphosis or Gerald and the Werewolf. Speculum 73: 987-1013.

Bynum, C.W. 2001. Metamorphosis and Identity. New York: Zone Books.

Cohen, J. J. 2000. Hybrids, Monsters, Borderlands: The Bodies of Gerald of Wales. In The Postcolonial Middle Ages, ed. J.J. Cohen, 85-104. New York: St. Martin's Press.

Echard, S. 1998. Arthurian Narrative in the Latin Tradition. Cambridge, UK: Cambridge University Press.

Faletra, M. 2014. Wales and the Medieval Colonial Imagination: The Matters of Britain in the Twelfth Century. New York: Palgrave Macmillan.

Fanon, F. [1963] 2005. The Wretched of the Earth. New York: Grove Press.

Flint, V. 1979. The Historia Regum Britanniae of Geoffrey of Monmouth and Its Purpose. A Suggestion. Speculum 54(3): 447-468.

Foucault, M. 1984. Nietzsche, Genealogy, History. In The Foucault Reader, ed. P. Rabinow, 76-100. New York, NY: Pantheon Books.

Geoffrey of Monmouth. 1957. Historia Regum Britanniae, ed. J. Hammer. Cambridge, MA: The Medieval Academy of America.

Geoffrey of Monmouth. 2008. The History of the Kings of Britain, trans. M.A. Faletra. Toronto, Canada: Broadview.

Gerald of Wales (Giraldus Cambrensis). [1863] 1968. The Historical Works of Giraldus Cambrensis, ed. T. Wright, trans. T. Forester. London: H.G. Bohn. 
Gerald of Wales (Giraldus Cambrensis). [1867] 1964. Giraldi Cambrensis Opera. Vol. 5, ed. J. F. Dimock. London: Longman \& co.

Gerald of Wales (Giraldus Cambrensis). 1937. The Autobiography of Giraldus Cambrensis, ed. and trans. H. E. Butler. London: Jonathan Cape.

Gerald of Wales (Giraldus Cambrensis). 1978. The Journey through and Description of Wales, trans. L. Thorpe. New York: Penguin.

Gerald of Wales (Giraldus Cambrensis). 1982. The History and Topography of Ireland, trans. J.J. O’Meara. New York: Penguin.

Ingham, P.C. and M.R. Warren. 2003. Postcolonial Modernity and the Rest of History. In Postcolonial Moves: Medieval through Modern, ed. P.C. Ingham and M.R. Warren, 1-18. New York, NY: Palgrave.

Heng, G. 2003. Empire of Magic: Medieval Romance and the Politics of Cultural Fantasy. New York: Columbia University Press.

Roach, J. 1998. Cities of the Dead. New York: Columbia University Press.

Scott, D. 2004. Conscripts of Modernity: The Tragedy of Colonial Enlightenment. Durham, NC: Duke University Press.

Searle, E. 1988. Predatory Kinship and the Creation of Norman Power, 840-1066. Berkeley, CA: University of California Press.

Shichtman, M. B. and L. A. Finke. 1993. Profiting from the Past: History as Symbolic Capital in the Historia Regum Britanniae. Arthurian Literature 12: 1-35.

Spiegel, G. 1983. Genealogy: Form and Function in Medieval Historical Narrative. History and Theory 22: 43-53.

Warren, M. 1998. Making Contact: Postcolonial Perspectives through Geoffrey of Monmouth's Historia Regum Britannie. Arthuriana 8(4): 115-134.

William of Newburgh. 1856. Historia Rerum Anglicarum, vol. 1, ed. H. C. Hamilton. London: English Historical Society. 